\title{
The Many Meanings of Iconoclasm: Warrior and Christian Temple-Shrine Destruction in Late Sixteenth Century Japan
}

\author{
Alan Strathern \\ Associate Professor of History, University of Oxford, UK \\ Fellow and Tutor in History, Brasenose College \\ alan.strathern@history.ox.ac.uk
}

\begin{abstract}
The conversion of certain warlords in Kyushu, Japan, (1560-1580 CE) represents one of the most important breakthroughs for Christianity in the early modern world, and it was accompanied by striking acts of destruction of the local sacred sites and objects. Yet shrine and temple destruction had already become a relatively commonplace feature of warfare in this period of internecine struggle, exemplified by the activities of Oda Nobunaga. How was the iconoclasm of Christian converts interpreted in this context? This article is particularly concerned with the implications of iconoclasm for a raging struggle of "empirical religiosity" - in which Christians and their opponents argued about the immanent power of the gods and their capacity to take revenge on iconoclasts. It also suggests that prevailing Buddhist and Confucian discourses presented important limits to how damaging such empirical arguments were to local religion. These issues are also explored in relation to the case of the Christianizing Ōtomo house, and their relations with the important Usa Hachiman shrine.
\end{abstract}

\section{Keywords}

iconoclasm - Japan - Christianity - Ōtomo Sōrin - Hachiman - Oda Nobunaga - conversion 


\section{Introduction}

Some of the most arresting incidents of Christian violence against sacred structures and images in the early modern world occurred in Japan. For they did not follow the imposition of Portuguese or Spanish jurisdiction but were rather the result of the fact that here, finally, missionaries had been able to bring about their most desired objective: the conversion of independent rulers. The breakthrough conversions were those of a group of warriors and warlords (daimyo) on the southern island of Kyushu. These were Ōmura Sumitada (1533-1587), who held a petty domain in the Sonogi peninsula and was baptized in 1563; Arima Yoshisada of the Takaku region close by, who was baptized in 1576, followed by his son Harunobu in 1580; and Ōtomo Sōrin of Bungo, whose baptism in 1578 was the most important of the lot. Sōrin's son and heir Yoshimune also came close to baptism, dithered this way and that, and was in fact briefly a baptized Christian in $1587 .{ }^{1}$ Just as the Jesuit mission strategy had intended, these baptisms led to rolling top-down movements of conversion amidst the conspicuous destruction of Buddhist and Shinto sites and objects.

Indeed, this behavior reflects a much broader pattern over the longue durée of world history: it was in fact quite common for rulers converting to Christianity to launch waves of iconoclasm. ${ }^{2}$ Why this should be so, however, is a more complex issue than it may appear at first glance. Would not such violence accentuate the legitimacy crises that ruler conversions typically precipitate? Moreover, as has become particularly clear in recent and controversial debates on temple destructions by Muslim elites in South Asia, what such acts signify - both to the people carrying them out and to the communities whose sacred sites are violated - is not a straightforward matter. ${ }^{3}$

In sixteenth century Japan there was another set of conditions that contribute a further layer of complexity to the issue. The reason why the Jesuits had managed to make such elite conversions in Japan - rarely replicated elsewhere in Asia - was because they arrived at the height of the Sengoku or civil war period, in which power had fragmented into the hands of dozens of competing

1 I therefore leave to one side another breakthrough case here: the conversion of three leading families in the Gokinai, the region around Kyoto, 1563-1564, following a debate (Luís Fróis, Historia de Japam, ed J. Wicki (Lisbon, 1976-1984, 5 vols.), I, 252-266).

2 For example, Kongo in the 149os, and Hawaii in the 1820s, discussed in Alan Strathern, Converting Kings: Kongo, Japan, Thailand and Hawaii Compared 1450-1850 (Cambridge, forthcoming).

3 A. Azfar Moin, "Sovereign Violence: Temple Destruction in India and Shrine Desecration in Iran and Central Asia," Comparative Studies in Society and History 57 (2015): 467-496, https:// doi.org/10.1017/Soo1041751500o109. 
warlords. ${ }^{4}$ These were engaged in a desperate struggle for survival and expansion, and intent on scavenging any outside sources of strength in order to advance their interests. ${ }^{5}$ In this context, Buddhist institutions had also been dragged into the business of war and politics, and therefore become subject to military reprisals and raids. Furthermore, Buddhism was split into distinct schools and institutional networks. Particularly significant were the popular movements of lay salvationism inspired by the Pure Land and Nichiren teachings, which tended to be more aggressive towards rival sects than had been the case hitherto. All of this meant that Christian iconoclasm entered into a world in which shrine and temple destruction was already a fact of life. Much of this activity was not iconoclastic in intent (a point to which I shall return), but the term is used here to refer to any act of destruction of sacred images and structures - which may have ideological and emotional repercussions regardless of the motives behind it. ${ }^{6}$ And if the Sengoku period rendered Japan plural and open in political terms, it was also a period of religious and philosophical innovation, receptivity, and argument.

Apart from exploring the motives, meaning, and consequences of daimyo iconoclasm, there is a more particular thesis I wish to explore here. However, articulating it will mean touching briefly on a theoretical framework advanced as part of the larger project of comparative history from which this article has emerged. ${ }^{7}$ In a recent book, I have outlined two forms of religiosity. Immanentism is the default mode of religious behavior: it is driven by universal cognitive tendencies towards imagining that significant processes of cause and effect are controlled by supernatural forces and beings who are present ("immanent") in the world and amenable to ritual communication. If the intent behind immanentist action is the amelioration of life in the here-and-now, the raison d'être of transcendentalism, by contrast, is salvation. This means attaining a newly transcendent state of being such that the human condition is escaped altogether through a process of abiding by a set of core teachings and moral injunctions. These teachings are attributed to individual prophets or thinkers and set down in texts, generating an authoritative clerisy to guard and interpret them. Thus, the guiding principle shifts from a matter of earthly

4 Another exception is Sri Lanka, where again there had been a fragmentation of power, Alan Strathern, Kingship and Conversion in Sixteenth-Century Sri Lanka: Portuguese Imperialism in a Buddhist land (Cambridge, 2007).

5 This inflamed the significance of "religious diplomacy" as explored in Alan Strathern, Unearthly Powers: Religious and Political Change in World History (Cambridge, 2019).

6 For a similar approach, see Fabio Rambelli and Eric Reinders, Buddhism and Iconoclasm in East Asia: A History (London, 2012), vii-x.

7 This framework is explained in detail in Strathern, Unearthly Powers. 
felicity to a regard for truth, ethics, and soteriology. It is important to note, however, that all traditions such as Christianity or Buddhism which have an overtly transcendentalist dimension also always function on an immanentist level (but the reverse is not true).

As will become clear, there is abundant evidence of a deeply immanentist and empirical dimension to religious life in Japan, which the life-and-death struggles of the civil war did nothing to abate. Transcendentalism was represented by various traditions of Buddhism (which also, on some level, incorporated immanentism). Zen Buddhism, for example, maintained a high regard for the counter-intuitive and apophatic qualities of Buddhist soteriology, while the Kamakura sects unleashed salvation as a more immediate lay imperative. ${ }^{8}$ But it was also in this period that a distinct strain of Confucian thinking became influential. ${ }^{9}$ This was - to resort to an awkward term - "quasi-transcendentalist" insofar as it represented a profoundly ethicized mode of life.

Now, a major reason why iconoclasm accompanies or follows ruler conversion is related to the logic of the immanentist imagination. Ancestors, spirits, or deities - what Marshall Sahlins refers to as "metapersons" - are intuitively understood as inhabiting or emotionally attached to their material instantiations. ${ }^{10}$ When the shrines or fetishes or temples built to honor them are destroyed it may be interpreted as a great affront, sure to rouse their anger. The key point is this: if the metapersons are seen to fail to respond then their power may be called into doubt and an opening created for the new deities to stake a claim to greater efficacy. ${ }^{11}$ Across the world, missionary and neophyte iconoclasm functioned as an exemplary theatre of supernatural warfare designed to destroy the feeling that giving up the worship of the old metapersons would be to invite their punishment. ${ }^{12}$

Such tactics had something in common with two behaviors that already existed in certain immanentist religious systems. For example, in some

8 I leave aside Daoism here. Meanwhile, local immanentism was also coalescing into an unusually self-conscious form - "Shinto" - under the influence of Buddhist discourses.

$9 \quad$ K. N. Paramore, Japanese Confucianism: A Cultural History (Cambridge, 2016).

10 David Graeber and Marshall Sahlins, On Kings (Chicago, 2017).

11 Consider the recent bombings in Sri Lanka (April 2019), in which St. Anthony's Church in Colombo was attacked. Widely associated with miraculous powers, one local commented "The people who did this are not human. But this is no ordinary church. It is powerful. They will pay," Gareth Evans and Mal Siret, "Sri Lanka Reels from Deadly Attacks," $B B C$ News, April 20, 2019, https://www.bbc.com/news/live/world-asia-480o2165.

12 On supernatural or spiritual warfare in anthropology, see Joel Robbins, "Transcendence and the Anthropology of Christianity: Language, Change, and Individualism (Edward Westermarck Memorial Lecture)," Journal of the Finnish Anthropological Society 37 (2012): $5^{-23}, 13$. 
expressions of what I refer to as warrior iconoclasm, the temples of enemies may be destroyed as a means of wiping out the ritual basis to their power, and proving the superior power of one's own tutelary deity. ${ }^{13}$ In other contexts, we might see auto-iconoclasm in action: this is where people are induced to turn on shrines and sacred objects because the metapersons they have been associated with are suddenly identified as harmful or malevolent. Both of these derive from the fundamental immanentist preoccupation with power as inextricably linked with supernatural relations. This entailed a deeply empirical sensibility, i.e. one predisposed to scrutinize happenings in the observable world as the consequence of ritual-supernatural agency. The iconoclasms urged by Christian missionaries also conformed to or resonated with this immanentist logic in profound ways. However, missionaries also conceived of iconoclasm in transcendentalist terms: righteous iconoclasm is violence deployed in the service of ethical and soteriological imperatives, as in the Christian conception of abomination.

Rambelli and Reinders' recent work has illuminated how temple destructions could indeed be connected with questions of divine efficacy in Japanese history over the long term. In one incident from 1165 described in the Tale of the Heike, warrior monks from Enryakuji on Mount Hiei attacked the temple of Kiyomizudera and tore down the buildings. "The morning after the temple had been burned down a notice appeared in front of the main gate stating, 'Ha! What is the matter with Kiyomizu Kannon, who once proclaimed that she could transform a pit of fire into a cool pond?"'14 In the thirteenth century the monks of Enryakuji temple had threatened to set their own temple buildings on fire in order to force the hand of the court - the idea was that the prospect of the disturbed kami (deity) withdrawing their protection would be too much for the court to bear. ${ }^{15}$

Yet clearly warriors were not paralyzed by the threat of divine displeasure attendant on temple destruction, and nor were temples automatically vulnerable to disconfirmation should such vengeance fail to become manifest. In part, this is simply because cleanly coherent understandings were not at work here: the religious imagination is not scrupulously intent on rationalization and consistency and often operates at the level of intuitive or non-reflective cognition. To the extent that explicit arguments did matter, there was always a reserve of what cognitive scientists have referred to as "conceptual control" available for defenders of temple and shrine deities, who could exploit ambiguities as

13 See Strathern, Unearthly Powers, 241.

14 Rambelli and Reinders, Buddhism and Iconoclasm, 61.

15 Rambelli and Reinders, Buddhism and Iconoclasm, 57-58. 
to when divine displeasure might be forthcoming or appeal to the opacity of divine will. For these reasons, the missionary stratagem of iconoclasm-asdisconfirmation was not reliably effective in any society.

And yet in some societies it evidently was a notably powerful tool at their disposal. ${ }^{16}$ I suggest that its power was diminished in settings, such as Japan, where other "transcendentalist" religions such as Buddhism had achieved a certain hegemonic role. In general, transcendentalism lifts the field of salient contention away from the empirical realm, engendering a particularly powerful form of conceptual control over such matters. But how much is this borne out by the evidence from Japan? How much of a threat, in the end, was Christian iconoclasm to the pre-existing "combinatory" religious field? And to what extent was Christian violence seen as equivalent to existing forms of iconoclasm?

In answering these questions, I have drawn particularly on Jesuit letters and the voluminous chronicle of Luís Fróis, but an important role is also played by some documents in Japanese. Many of these relate to the case of Bungo 156o1580, and the relations of its lords Ōtomo Sōrin and Yoshimune with the Usa Hachiman shrine in Buzen. I begin, however, by considering some of the immediate contexts and motives behind iconoclastic activity within the domains of converting Kyushu warlords. We shall then pan out, second, to appreciate the much broader clash between warriors and religious institutions taking place in this period, and the political, military, and economic matters at stake. Third, these dynamics are related to the local case study of Bungo, in which certain rather material preoccupations are visible in the relationship between Christianizing lords and the existing temples and shrines in their territories. The fourth section proceeds to explore the religious meanings of iconoclasm, the implications of Oda Nobunaga's actions and the way in which transcendentalist discourses allowed for various paradoxical conclusions to be drawn. The fifth part returns to the Usa Hachiman shrine to consider how these discourses worked at a more specific level. At one level, Hachiman might be understood as a "god of war," but his conceptualization was much more complex than this, and unlikely to be widely undermined by either warrior or Christian violence against his sacred abodes. Lastly, sixth, I examine the extent to which Christian iconoclasm was seen as conceptually distinct from other forms in Japan.

16 Strathern, Unearthly Powers, 255-295. 


\section{Daimyo Conversion and Agency in Christian Iconoclasm}

The initial context in which many of the elite conversions in Japan - as elsewhere - must be understood is that of "religious diplomacy," in which the patronage of or outright conversion to Christianity is seen as a means of securing certain political, diplomatic, and material advantages. ${ }^{17}$ In the case of Japan, this took the form of the opportunities arising from forming an association with the Portuguese, luring the carrack full of Chinese silk to call at their ports, gaining access to trade, gunpowder, and firearms. A minor lord of the territory of Sonogi in Hizen facing much internal division, Ōmura Sumitada, was approached with the promise of "great spiritual and temporal profits," the carrack called at his harbor of Yokoseura in 1562 and the following year he was baptized. ${ }^{18}$ Sumitada's brother, Arima Yoshisada (1521-1576), who held a lordship in the Shimabara peninsula, also formed an association with the Jesuits in that year. In 1576 he finally converted and left thousands of converts among his subjects when he died. ${ }^{19}$ His son, Arima Harunobu (1567-1612), began his rule by persecuting these subjects, but faced with both internal dissension and external threats he too was also drawn by the carrack and the prospect of military assistance, and in 1580 was baptized. ${ }^{20}$ Such factors played a much less significant role in the conversion of Ōtomo Sōrin and Yoshimune, however.

In all these cases, iconoclastic actions formed part of the conversion process. Three forms of agency were involved. First, the proto-accommodative tendencies of the Jesuits certainly did not extend to countenancing any aspects of Buddhism or kami worship. At times, they actually participated in the violence, and at other times they encouraged it. ${ }^{21}$ Second, converted daimyo were willing and able to execute this violence as a matter of policy. And third, there

17 Strathern, Unearthly Powers, 257, presents a threefold model of ruler conversion: (1) religious diplomacy, (2) accessing immanent power, (3) enhancing authority. These represent the primary modes of attraction, but also tended to follow consecutively.

18 Fróis, Historia de Japam, I, 270-271; Alessandro Valignano, Historia del principio y progresso de la Compañía de Jesús en las Indias orientales (1542-64), ed. J. Wicki (Rome, 1944), 444-446; Jurgis Elisonas, "Christianity and the Daimyo," in The Cambridge History of Japan, Vol. 4: Early Modern Japan, ed. John W. Hall (Cambridge, 1991), 301-372, 323-324.

19 Fróis, Historia de Japam, I, 298-304; II, 449-454.

20 Fróis, Historia de Japam, III, 133-145.

21 See Higashibaba Ikuo, Christianity in Early Modern Japan: Kirishitan Belief and Practice (Leiden, 2001), 92; George Elison, Deus Destroyed: The Image of Christianity in Early Modern Japan (Cambridge, MA, 1973), 131; Andrew C. Ross, A Vision Betrayed: The Jesuits in Japan and China, 1542-1742 (Edinburgh, 1994), 53; Carla Tronu Montané, "Sacred Space and Ritual in Early Modern Japan: The Christian Community of Nagasaki (156o-1643)," (PhD Thesis, soAs, University of London, 2012), 58-62. 
was a measure, somewhat hard to quantify, of popular enthusiasm among the neophytes.

In the early case of Ōmura, the role of Jesuit urgings is blatant. ${ }^{22}$ The most extensive iconoclastic sweep here came after the Jesuits made it clear that this would be an appropriate way to repay the favor shown by the Portuguese to the daimyo when he was rescued by the timely arrival of four of their vessels in $1574 .{ }^{23}$ Gaspar Coelho even led the action. ${ }^{24}$ As for Harunobu of Arima, he may have begun his career by destroying Christian structures, but after Valignano had also engineered his survival he, too, was ready to comply with the other side of the bargain, ordering the destruction of all the temples of the gods and Buddhas, more than forty in all, and including some of the most beautiful and renowned in Japan. ${ }^{25}$ Here, as elsewhere, Buddhist monks were married or evicted. As Fróis put it, Arima understood how much in both body and soul he owed to the church. ${ }^{26}$ In territories where lords converted who were below the daimyo level but with sufficient independence of action, the picture is the same, as with Amakusa Shigehisa (Dom Miguel), who was baptized in 1571 and oversaw a destruction of temples in $1577 .{ }^{27}$ Shimabara in the 158 os saw particularly clear examples of top-down iconoclasms with Jesuits playing a leading role. ${ }^{28}$

The Jesuits evidently tutored converts that becoming Christian meant destroying all the domestic shrines and figures in their own possession and developing a robust disgust for them more generally. ${ }^{29}$ In the first wave of iconoclasms instigated by Gaspar Vilela, it was noted that "those who received little information of Christianity were seized by great horror and astonishment, fearing that they would receive some punishment from the kami and

22 Luís Fróis, 14 Nov 1563, Ōmura, in Cartas qve os padres e irmãos da Companhia de Iesus escreverão dos Reynos de Iapão \& China aos da mesma Companhia da India, \& Europa, des do anno de 1549 atè o de 158 o. Primeiro tomo ... Impressas por mandado do Reverendissimo em Christo Padre dom Theotonio de Bragança Arcebispo d'Evora [facsimile edition of the 1598 Évora edition. Vol. 1: 1549-1580; Vol. 2: 1580-1588] (Maia, 1997) (henceforth simply "Cartas"), vol. 1, ff. 134-134v.

23 Elisonas, "Christianity and the Daimyo," 228.

24 Cabral, 12 Sept 1575, Nagasaki, Cartas ff. 350-52v; Luís de Almeida, 31 Jan 1576, Kuchinotsu, Cartas ff. 370-371; Fróis, Historia de Japam, II, 424, 430.

25 Elisonas, "Christianity and the Daimyo," 334.

26 Fróis, Historia de Japam, III, 148.

27 Elisonas, "Christianity and the Daimyo," 333; note Fróis, Historia de Japam, v, 5 ०3.

28 For later top-down iconoclasms in this region see Fróis, Historia de Japam, IV, 497, 503; v, 168; Higashibaba, Christianity in Early Modern Japan, 93. On the case of Gaspar Vilela in Ikitsukijima, see Ross, A Vision Betrayed, 47.

29 This includes one of the early Gokinai converts baptized in 1564, Takayama Ukon no Suke or Dom Justo (1552-1615), see Elison, Deus Destroyed, 126-127. 
the hotoke [the gods and buddhas]."30 The first breakthrough among the nobility of Bungo in 1576 saw young noblemen and servants alike instantly express their conversion through an apparent hatred for local cult images. ${ }^{31}$ Ötomo Sōrin's wife stiffened her opposition to Christianity as a result, though Fróis notes that her initial reaction on receiving reports of this violence was to reply that if the kami were indeed powerful they would be able to take their own revenge for the destruction of their temples. ${ }^{32}$ Part of the final stage of the conversion of Sōrin himself in 1578 involved him taking two precious Buddhist images that he had venerated in his house, throwing them to the floor and ordering that the bits be thrown into the sea. ${ }^{33}$ It seems, then, that the energies roused by the personal dramas of abnegation enacted by elite converts could pour over into more public acts of desecration. ${ }^{34}$

Indeed this point surely extends beyond the elite too, and means that at times there was an element of popular enthusiasm at work. ${ }^{35}$ Given how closely the spread of Christianity among members of the Bungo elite was associated with the drama of exorcism and healing, part of the explanation lies in the willingness of some Japanese to suddenly reimagine the kami and hotoke (Buddhas) as malign agents whose power must be broken through the destruction of their abodes. No doubt this was assisted by pre-existing notions that ill-health could be caused by demonic metapersons and potentially reversed through ritual action (especially by yamabushi, Shugendō practitioners). ${ }^{36}$ In this sense, Christian iconoclasm came close to the forms of auto-iconoclasm

$30 \quad$ Fróis, Historia de Japam, I, 118-119.

31 Cabral, 9 Sept 1576, Kuchinotsu, Cartas, ff. 356-358v. Sōrin's second son Chikaie (baptized as Sebastião in 1575), for example, immediately called together his Christian companions to walk the roads and display their Christianity by destroying a temple, while the servant Estevão refused to even touch a picture of a temple.

32 Cabral, 9 Sept 1576, Kuchinotsu, Cartas, f. 36 ov. This should be treated with caution as Cabral may be deploying a rhetorical maneuver here, inserting a prophecy that does not come true in order to prove the opposite, or it could be a rationalization of inaction on the part of Sōrin's wife who was otherwise painted as such an implacable foe of Christianity (and calumnied as "Jezebel").

33 Fróis, Historia de Japam, III, 22.

34 As is indicated in Cartas, Cabral, 9 Sept 1576 , Kuchinotsu, ff. $355 \mathrm{v}-363 \mathrm{v}$.

35 Relatively plausible mentions of spontaneous and popular outbreaks in Fróis, Historia de Japam, II, 424-425; III, 118; IV 503, and (possibly) João Francisco,14 Sept 1575, Ömura, Cartas, f. 355 . Note also the iconoclasm of the community who had converted en masse in 1576 in the hope that they would be liberated from demonic afflictions: Aires Sanches, 8 Sept 1576, Hirado, Cartas f. 373.

36 Allan Grapard, Mountain Mandalas. Shugendō in Kyushu (London, 2016), 171 and Alan Strathern, "Immanent power and empirical religiosity in the conversion of the daimyo of Japan, 1560-1580," Journal of Japanese Religious Studies (forthcoming). 
we see in immanentist settings, as the local deities were denied neither power nor reality, but were rather suddenly reconceived as malevolent beings who could be overmastered. The sense of abandonment experienced by the sick and ailing was part of what allowed this cognitive shift to take place.

The themes of iconoclasm, disconfirmation, exorcism, and supernatural warfare are particularly explicit in the Portuguese evidence regarding the immediate aftermath of Sōrin's baptism in August 1578. Some weeks later, Sōrin led a force of samurai decked out in Christian symbols into the territory of Tsuchimochi in Hyūga determined to found a new society inspired by what he had had heard of Europe. Three captains were sent to the region to destroy the two most important temple-monastic complexes. ${ }^{37}$ But this reflected more than the desire to clear the ground for churches, or a zealous appreciation of the principle of abomination. ${ }^{38}$ Only one of the captains was a Christian - and interestingly also a lay exorcist who had taken into his own hands the power of the new God to dispel demons. Fróis' contemporary letter describes the ways in which this man, referred to as Gião, deliberately dishonored these sacred spaces so venerated by the other soldiers and then set them on fire: "This caused new amazement among the natives of the land and they said amongst themselves that they could not understand how it was possible for this to go unpunished." They then moved on to a most significant shrine located on the banks of the Mimigawa river. This was dedicated to Sumiyoshi Daimyōjin and associated with the naval exploits of the legendary first emperor Jimmu. ${ }^{39}$ When the destruction of this shrine was also left unavenged, Gião's two fellow captains sought baptism. ${ }^{40}$ In other words, iconoclasm was not simply an expression of Christianity, but was also a means of making Christians - by provoking local deities and emphasizing the failure to respond. ${ }^{41}$

37 Fróis, Historia de Japam, III, 31-32; 37-39; Michael Cooper, ed., João Rodrigues's Account of Sixteenth-Century Japan, (London, 2001), 100.

38 See also Kanda Chisato "Ōtomo Sōrin no kaishū: sono jittai to haikei 大友宗麟の改 宗：その実態と背景 [The Conversion of Ōtomo Sōrin - Circumstances and Context]" Bulletin of Toyo University, Department of History, the Faculty of Literature 40 (2014): 71-110, 96 .

39 I am grateful to an anonymous reader for the journal for identifying this temple and providing this information. They also noted that the subsequent battle of Mimigawa that was fought in this vicinity, which was such a disaster for the Christian party, may have been interpreted as the deity's reply! The arguments around this battle are discussed in Strathern, "Immanent power and empirical religiosity."

40 Luís Fróis, 30 September 1578, Usuki, Cartas ff. 407-408.

41 Around this same time, Yoshimune is reported as claiming that he was engaged in dismantling temples "so that the lords of the land may come to understand by these means 


\section{Buddhist Leagues, Shrines, and Temples and the Clash with Warrior Ambition}

The avidity with which Christianizing warlords took to this enterprise may also be explained in terms of a much broader dynamic, however, the struggle between secular and religious institutions for power in the Sengoku period. In the vacuum created by the decayed authority of the emperorship, the Shogunate and the ancient nobility, power was both fragmented and reformulated in the guise of an ascendant warrior class of daimyo - now ruling over their subject populations with unprecedented comprehensiveness. ${ }^{42}$ At the same time, various Buddhist institutions were prompted to translate their social power into political authority. This took two forms. First, the schools of Kamakura Buddhism (the Jōdo Shinshū, or True Pure Land lineages, and the Hokkeshū, or Lotus Sutra lineage founded by Nichiren) flourished into movements of popular salvationism, or leagues $(i k k i)$, which amounted to a radically new form of political authority. The most significant of these was the Ikkō-ikki (singleminded league), which developed around the Jōdo Shinshū leadership of Rennyo. Second, shrines and temple complexes - especially the long-standing and well-endowed Tendai and Shingon temples - became political and military players in their own right. They controlled vast tracts of productive land and many lucrative commercial centers. ${ }^{43} \mathrm{Head}$ temples might wield authority over a network of hundreds of branch temples beneath them. They could enjoy effective extra-territoriality as legal sanctuaries, and also became places to which people entrusted their families and belongings when setting off for war. ${ }^{44}$ Above all, richly endowed temples developed their own bodies of troops. In more subtle ways too, temples and shrines had political weight - they gave oracles, received revenues, sent presents - and their submission or allegiance was therefore sought by daimyo. If we further consider the growing tensions between different forms of Buddhism, it is no surprise that from the eleventh century onwards conflict between temples and warriors, between rival sects,

the little advantage that their idolatries brought them" - i.e. showing that their promise of immanent power was a delusion: Luís Fróis, 16 Oct 1578, Usuki, Cartas ff. 415v-428.

42 K. N. Paramore, "Christianity as Feudal Virtue or as Civilization Mission? Mission Strategy and Contra-Individualization in Japan and China (156o-1860)," in Individualisierung durch christlische Mission? eds. Martin Fuchs, Antje Linkenbach, and Wolfgang Reinhard (Weisbaden, 2015), 403-420, 406.

43 Neil McMullin, Buddhism and the State in Sixteenth Century Japan (Princeton, 1984).

44 Ōtomo-shi toshiyori rensho shojō an 大友氏年寄連署書状案 [Copy of a letter with cosignatures of the senior councilors of the Ōtomo clan], document 418, in Ōita-ken shiryō 大分県史料, vol. 24, ed Ōita-ken shiryō kankōkai 大分県史料刊行, Ōita: 1952-1977; discussion in Kanda, “Ōtomo Sōrin no kaishū," 77. 
and even between rival temples of the same sect became relatively common. ${ }^{45}$ When Valignano arrived in 1579 he was struck by the propensity of the Japanese to destroy temples of any sect during military invasions. ${ }^{46}$

All this served to undermine the fundamental principle of the interdependence of secular rule and sangha expressed in the ōbo-buppō formulation (normally translated as "Imperial law" - "Buddhist law").47 The capacity of Buddhism to fulfil the Durkheimian function of social cohesion at the level of the region or Japan itself was seriously limited: the stage was set for a showdown between the relatively "secular" authority of the daimyo, and the great temple complexes and popular leagues that stood in their way. 48

This contest between politicized Buddhism and the newly ambitious warriors intent on asserting the primacy of the state reached its apogee, of course, with the campaigns of Oda Nobunaga, who was engaged in what Neil McMullin described as nothing less than "a redefinition of the 'place' of Buddhism in Japanese society," such that it was removed from the center stage and relegated to a distinctly subordinate role. ${ }^{49}$ For Fabio Rambelli, Nobunaga "for the first time broke the taboo against a radical rejection of Buddhist institutions in Japan." ${ }^{\prime 5}$ When he was overseeing the building of Nijō palace in 1569 and his castle of Azuchi in 1576, he deliberately ordered that Buddhist statues and architecture be cut up and used as mere masonry for his own projects, thus

45 Rambelli and Reinders, Buddhism and Iconoclasm, 54; Richard Bowring, The Religious Traditions of Japan 500-1600 (Cambridge, 2005), 217-218; Thomas Conlan, From sovereign to symbol: an age of ritual determinism in fourteenth century Japan (Oxford, 2011), 9; Christopher M. Mayo, "Tachibana Dōsetsu's Thoughts on Warrior society and Religion in Sixteenth-Century Japan," Kōgakkan Shigaku 皇學館史學 30 (2015): 64-32, 57, 50; McMullin, Buddhism and the State, 22.

46 "It is the custom of the Japanese to destroy everything they take, whether temples of their own sects or those of others, without paying the smallest respect to the very idols they worship," Charles R. Boxer, The Christian Century in Japan, 1549-1650 (Berkeley, 1951), 100.

See it referenced in a 1562 shrine vow by Ōtomo vassals, in Zōho teisei hennen Ōtomo shiryō 増補訂正編年大友史料, ed. Takita Manabu 田北学 (1962-1971) [henceforth ZTHOS ], vol. 21, doc. 223, pp. 114-115. According to McMullin, Buddhism and the State, 23-24, buppō takes in the major temple-shrine complexes which had of course incorporated Shinto elements, while Kuroda Toshi and Jacqueline I. Stone, "The Imperial Law and the Buddhist Law," Japanese Journal of Religious Studies (1996): 271-285, 276, explains that $\bar{o} b \bar{o}$ referred to worldly authority conceptualized in Buddhist terms. James F. Baskind and Richard Bowring, eds., The Myotei dialogue: a Japanese Christian critique of native traditions, (Boston, 2015), 189, use "King's Law."

48 Herman Ooms, Tokugawa Ideology: early constructs, 1570-1680 (Princeton, 1985), 20.

49 McMullin, Buddhism and the State, 5.

$5^{\circ}$ Rambelli and Reinders, Buddhism and Iconoclasm, 64; and see Bowring, The Religious Traditions of Japan, 429 . 
flaunting a symbolism of the subjection of Buddhism to the construction of the state. ${ }^{51}$

One of his most resonant acts in this vein was the massacre of monks at the Tendai complex of Enryakuji on Mount Hiei in September 1571 in retaliation for their assistance of enemy daimyo. With a measure of wondering schadenfreude, Fróis reports that its hierarchs never believed Nobunaga would dare launch an attack on them, for the punishments of its god Sannō, residing at the summit, would be too intimidating. Yet thousands of monks and laity had perished nonetheless in a week long orgy of violence. ${ }^{2}$ This caused great shock, which lends some credence to McMullin's argument that Nobunaga's confrontation with the militant temples was felt to have cast aside the fundamental principle of $\bar{o} b \bar{o}-b u p p \bar{o} .{ }^{53}$ The destruction of Enryakuji aroused a substantial backlash responding to the rallying cry of Kennyo (1543-1592), the abbot of Ishiyama Honganji in Osaka, who wielded much influence over the Ikkō-ikki. Galvanized by the salvationist teachings of Jōdo Shinshū (True Pure Land) Buddhism, they would inevitably clash with ambitious daimyo schemes of unification. ${ }^{54}$ They proved, in fact, the most obstreperous obstacle to Nobunaga's will-to-power, and his decade long campaign (1570-1580) against them culminated in their fortress-temple complex being burned to the ground. In hindsight, his crushing of Honganji and Enryakuji were the first steps towards the decisive subordination of religious institutions that would be firmly established under the Tokugawa shoguns. ${ }^{55}$

\section{The Ōtomo and the Clash with Buddhist Power}

Relations between the Ōtomo and the principal shrines and temples of the territory they governed in the 156 os-159os may be seen as a microcosm of these thunderous power struggles at the national level. The Ōtomo expansion brought under their control one of the most important religious centers in Japan, the Usa Hachiman shrine in Buzen, which acted as the head of an extensive network of shrines. The significance of Hachiman, associated with

\footnotetext{
51 McMullin, Buddhism and the State, 86.

52 Luís Fróis, 4 October 1571, Cartas ff. 332r-v.

53 McMullin, Buddhism and the State, 257.

54 Ooms, Tokugawa Ideology, 22, 31.

55 Victor B. Lieberman, Strange Parallels: Southeast Asia in Global Context, c.80o-1830 (Cambridge, 2003), ii, 444-445; McMullin, Buddhism and the State, 4-5.
} 
military victory, the imperial line, and the protection of Japan itself, is underscored below. 56

The Ōtomo association with the Usa shrine was not longstanding, however, having previously patronized the Ōhara Hachiman shrine in Hida in the west and most especially the Yusuhara Hachiman shrine located close to Funai, which was the family's tutelary deity. ${ }^{57}$ Indeed, relations with Usa Hachiman itself remained somewhat ambivalent. By this time, it had become a significant political and military player in the game of the Sengoku, with a fort and a troop of soldiers (shinpei - god's army). Indeed, it had also grasped the distinctly "early modern" opportunities opened up by the expanding maritime economy of Kyushu, being involved in ship-building, banking, and silver flows. ${ }^{58}$ No wonder that Sōrin sought to exert some control over it. ${ }^{59}$ The Nata family, who provided high priests to the shrine, had become influential vassals of the Ōtomo: Sōrin married the Nata daughter in 1545, while her brother Tawara Chikakata was a close advisor. But the shrine must have tried to retain its independence in the face of Sōrin's expansion for he made Tawara Chikakata directly responsible for it, and in 1561 and 1576 he actually attacked the shrine, burning down its buildings. ${ }^{60}$ When we consider that the Ōtomo burned down the shrine again then in 1581, this time after Sōrin's baptism, it seems less firmly a testimony to a Christian worldview, and rather more in keeping with a longer pattern. Again, the area was part of contested ground that had rebelled against Ōtomo hegemony. ${ }^{61}$ (The fortified shrines of Mount Hiko, a major Shugendō sacred site, were also attacked in 1581 by Ōtomo forces - having previously become a battleground for the warlord houses of Kyushu. ${ }^{62}$ Indeed, other post-baptism attacks on sacred sites may also have had a military-political dimension, such as the attack on the Rokugōsan Gongen shrine temples in 1578, which allowed the recruitment of its yamabushi as soldiers.

Viewed in this light, it appears that there were already tensions between the rising daimyo and religious institutions to which Christianity could provide a kind of radical articulation or even solution. By 1578 Sōin was in retirement,

\footnotetext{
56 In the section "The Usa Hachiman Shrine revisited."

57 Toyama Mikio 外山幹夫, Ōtomo Sōrin 大友宗麟, (Tokyo, 1975), 75-76.

$5^{8}$ Maria Grazia Petrucci, "Cast in silver: the rise and demise of Kyushu corsairs in a unifying Japan, 1540-1640," (DPhil thesis, University of British Columbia, 2017), 117-118.

59 Haruko Nawata Ward, Women Religious Leaders in Japan's Christian Century: 1549-1650 (Farnham, 2009), 123-124.

6o Ōita-ken shiryō, vol.24, documents 417, 418; Ward, Women Religious Leaders, 124, footnote $5^{2}$.

61 Fróis, Historia de Japam, III, 320; Ward, Women Religious Leaders, 177.

62 Cf attacks by the Ryūzōji house in 1568: Grapard, Mountain Mandalas, 164, 197.
} 
having left the governance of the realm to his son Yoshimune - this was indeed one of the factors which allowed him to finally accept baptism, in August of that year. The Jesuits considered that Yoshimune was being drawn further and further into Christianity over the same time period. I have argued that both he and his father were influenced by the apparent success of Christian rituals and objects in providing victory in battle and healing miracles. ${ }^{63}$ Whatever was really driving Yoshimune's behavior, the Jesuit reports are credible in describing him as engaged in an act of repeatedly testing and undermining the efficacy of the traditional ritual systems and the metapersons they engaged. ${ }^{64}$ Within a month of his father's conversion, he was requesting the attendance of a preacher, and asking about the miracles of Francis Xavier. ${ }^{65}$ He claimed that he could not yet convert but that if he steadily took revenues away from the monks and dismantled their temples then his noble vassals would come to see how little they in fact owed to the assistance of native gods. ${ }^{66}$

In fact, that year, he systematically refused to participate in all the major acts of Ōtomo patronage, including the act of giving alms to yamabushi from the three temples of Kumano Gongen and to devotees of Amida during the Bon festival. He also abandoned the procession at Funai in honor of Hachiman. ${ }^{67}$ Both contemporary Portuguese reports and later Japanese chronicles concur that Sōrin or Yoshimune also ordered all "public sorcerers" to be put to death, along with yamabushi from other territories, and any itinerant monks from Mount Kōya (kōya hijiri) who dared to return next year - an edict that was only softened at the urgings of a minister. ${ }^{68}$

The Jesuits may have exaggerated Yoshimune's rough-and-ready skepticism towards the kami and the Buddhas. ${ }^{69}$ But he does appear to have acquired an inclination to cut their representatives down to size. Francisco Cabral reports

63 Strathern "Immanent power and empirical religiosity;" and compare Kanda, "Ōtomo Sōrin no kaishū."

64 Cartas Luís Fróis, 5 June 1577, Usuki, f.373v-386; Luís Fróis, Usuki, 16 Oct 1578, f. 425; And also, in the chronicle Fróis, Historia de Japam, III, 26-37.

65 Fróis, Historia de Japam, III, 29-31. Yoshimune was clearly interested in Christianity's powers of exorcism and the miraculous, and in the power of the cross in particular: Luís Fróis, Oct. 1578, Usuki, Cartas, ff. 428r-v, 43ov.

66 Fróis, Historia de Japam, III, 31; Luís Fróis, 16 Oct 1578, Usuki, Cartas f. 424v.

67 Fróis, Historia de Japam, III, 33; Luís Fróis, Usuki, 16 Oct 1578, Cartas ff. 425r-v; also Ward, Women Religious Leaders $145^{-148 .}$

68 Fróis, Historia de Japam, III, 35; Ōtomo-ki 大友記 [Record of the Ōtomo]. Gunsho ruijū 群書類従, vol. 397 (Tokyo, 1989), 565; Intoku taihei ki (陰徳太平記), Book 2, volume 58 (Tokyo, 1913), 272-273. For differences between the Portuguese and Japanese accounts, see Strathern, "Immanent power and empirical religiosity."

69 Cabral, 9 Sept 1576, Kuchinotsu, Cartas, f. 359; Fróis, Historia de Japam, III 10, 31-33. 
that in 1576 Yoshimune had ordered a debate between a Christian and any parties who opposed Christianity and had declared the Christian the winner. ${ }^{70}$ Note that this predated Oda Nobunaga's pitched debate between Nichiren and Pure Land sects held at Azuchi in $1579 .{ }^{71}$ In comparative terms, formal debate has been deployed by other rulers who wish to curtail the powers of over-mighty religious establishments. The Mughal emperor Akbar, for example, also welcomed Jesuit missionaries to take part in grand disputations in the 1570 as a means of asserting his primacy over the Islamic religious establishment. ${ }^{72}$ Thus was the ruler placed as an adjudicator above the clerics squabbling below, and a kind of insidious relativism set to work on their authority.

To invoke yet another sixteenth century global counterpart, however, evidently Yoshimune also increasingly eyed the temples and monasteries in the manner of Henry VIII of England - as tempting reserves of financial capital that should properly be deployed by the state. ${ }^{73} \mathrm{He}$ was not alone among ambitious daimyo in making such calculations. ${ }^{74}$ Thus, in 1578 , he began to divert their revenue to his own vassals, particularly youths of his own generation who were given license to dispossess monks and monasteries for the smallest misdemeanor. ${ }^{75}$ The monks were cast onto the streets, alluding to astrological signs of the calamity befalling them. ${ }^{76}$ Yoshimune envisaged that they

70 Cabral, 9 Sept 1576, Kuchinotsu, Cartas, f. 357v. We don't need to countenance Cabral's claim that the Christian side "won," merely that Yoshimune chose to call it this way.

71 The Azuchi disputation between the Hokke and Jōdo Shinshū sects allowed Nobunaga to decisively clamp down on the activities of the former: Ōta Gyūichi, The chronicle of Lord Nobunaga, ed. and trans. Jurgis Elisonas and J.P. Lamers (Leiden, 2011), 314-321; Fróis, Historia de Japam, II, 249-250.

72 Moin, "Sovereign Violence," 133.

73 This is one reason why we should lay aside the over-heated claims of Christian affinity and piety on the part of Yoshimune in our Jesuit sources. The Jesuits did recognize this motive, however: see Francisco Carrión, 10 December 1579, Kuchinotsu, Cartas, f. 439v. See also Fróis, Historia de Japam, IV, 155, in which Dom Paulo later claimed that Yoshimune had secretly burned down a famous temple in Funai in order to restore his fortunes and use the wealth to pay his armies - and that he would do likewise.

74 Miguel Vaz, 3 September 1576, Arima, Cartas f. 371v, describes the padres' hopes for the conversion of the dynamic daimyo of Saga, Ryūzōji Takanobu (1529-1584), who had recently formed an alliance with Dom Bartolomeu. Ryūzōji is described as no friend of the "pagodes" (idols or temples) and the monks in general and wishing to give their revenues to his soldiers. The admission that there was one temple he did revere shows how secular his motives were. For the broader perspective of Nobunaga and other daimyo selectively confiscating temple properties and commercial centers see, McMullin, Buddhism and the State, $42,162-165$.

75 Luís Fróis, 16 Oct 1578, Usuki, Cartas f. 424v.

76 Fróis, Historia de Japam, III, 11-12. This might refer to the End of the Dharma - see below. 
could be drawn into the army, and thus their useless vocation exchanged for one that could benefit the state. These moves do coincide with a period in which Yoshimune was most drawn towards the Jesuits, but we know that in 1582 Yoshimune was still apportioning lands that had belonged to temples to his retainers, even while he had dropped his affiliation with Christianity. ${ }^{77}$ Fróis himself noticed that the more panoramic perspective had to be adopted on these events, for he implicitly compares Yoshimune's actions to those of Oda Nobunaga.

\section{The Religious Meanings of Iconoclasm}

But if there was a broader military, political, and financial dynamic behind attacks on local sacred spaces by converted or Christian-leaning daimyo, what were the religious implications? ${ }^{78}$ What difference did this colossal clash make to the range of interpretations of iconoclasm that could be advanced on the ground? For the missionaries, of course, the conclusion was clear. The point that Fróis wished to draw from his discussion of Nobunaga's violence against Buddhist institutions was that it entirely undermined the argument of antiChristian polemics: for rather than suffering from the vengeance of the gods, Nobunaga enjoyed the most spectacular rise of all in this period - indeed his ascension was almost uncanny. ${ }^{79}$ According to Fróis, the young Yoshimune observed this and sought consciously to imitate the great man..$^{80}$ Indeed, we know that the Jesuits were already making this argument about Nobunaga in relation to the conversion of Tawara Chikakata's adopted son, Chikatora in $1577 .^{81}$ It is indeed plausible that Nobunaga's actions helped weaken the threat of divine vengeance and made the trashing of sacred symbols ever more thinkable for ambitious warriors - whether they were drawing closer to Christianity or not. ${ }^{82}$ Clearly Nobunaga thought that he could easily do without the

$77 \quad$ ZTHOS, vol.26, doc. 98 .

78 Rambelli and Reinders, Buddhism and Iconoclasm, $76-81$, contra purely political explanations of temple destruction.

79 Fróis, Historia de Japam, III, 11.

8o Luís Fróis, 16 Oct 1578, Usuki, Cartas f. 424. No doubt the Jesuits themselves also seized it to stock their rhetorical arsenal.

81 Luís Fróis, 5 June 1577, Cartas f. 377v: the "pagans" had been hoping for divine punishment on Nobunaga for his shrine and temple destruction but "on the contrary the more that he destroyed them the greater became his estate, fame and riches."

82 McMullin, Buddhism and the State, 26o quotes Hirata Toshiharu: Nobunaga "conquered all fear of the Kami and Buddhas and of the buppō." See Wakita Osamu, "The Emergence of the State in Sixteenth-Century Japan: From Oda to Tokugawa," The Journal of Japanese 
supernatural protection that the ancient establishment of Enryakuji had long claimed that it provided for Kyoto. ${ }^{83}$

This remained, of course, only one of a range of attitudes that one might adopt. As always, the ambiguity of timing gave defenders of the gods a degree of "conceptual control," especially amid the incessant vicissitudes of war. Therefore in April of 1573 Fróis reports that some had attributed a recent military setback of Nobunaga's to the punishment of the kami and the Buddhas - outraged by his burning down the temple of Enryakuji on Mt Hiei two years beforehand and other such acts. ${ }^{84}$ But Fróis' report of Nobunaga's response is also credible - that he laughed at all this and said "in Japan he himself is the living kami and hotoke not the rocks and trees." $\$ 5$

No doubt only a character such as Nobunaga in an era such as the Sengoku jida - an embodiment of the forces of creative destruction and explicitly transgressive in his self-presentation - could have asserted the warrior's prerogative in such a ruthless manner. He may have been assisted here by an instinctively irreverent sensibility, a heady sensation (to which other great conquering rulers have also been prone) that he had escaped the structures of religious life no less than the political, or even a kind of ultra-transcendentalist deprecation of the immanentism of popular religiosity informed by currents of Zen thinking. ${ }^{86}$ And the common historiographical interpretation that he indulged

Studies 8 (1982): 343-367, 362, https://doi.org/10.2307/132343, for examples of similar behavior by two other daimyo.

83 McMullin, Buddhism and the State, 259.

84 Luís Fróis, 20 April 1573, Cartas f. 343.

85 Note that this comment is also intriguing evidence of a sense of self-deification on the part of Nobunaga (a hugely controversial matter in the historiography) - recorded long before Fróis's report of this issue in 1582 . The latter account has often been attributed to the need of the Jesuits to explain Nobunaga's downfall.

86 Fróis, Historia de Japam, II, 266-267, 171; Luís Fróis, 1 June 1569, Cartas, ff. 257v, 26ov, $264 \mathrm{r}-\mathrm{v}$ on his "despising the kami and hotoke" for example; and see Jurgis Elisonas, Warlords, Artists \& Commoners: Japan in the Sixteenth Century (Honolulu, 1981), 66; J. F. Moran, The Japanese and the Jesuits: Alessandro Valignano in Sixteenth-Century Japan (New York, 1993), 75-78; McMullin, Buddhism and the State, 80-91, 220-221; Kawamura Shinzo, S.J, "Communities, Christendom, and the Unified Regime in Early Modern Japan," in Christianity and Cultures: Japan \& China in comparison, 1543-1644, eds. M. Antoni and J Üçerler (Rome, 2009), 151-168, 157. For earlier examples of a skeptical, secular attitude to temples, see Rambelli and Reinders, Buddhism and Iconoclasm, 85; Boxer, The Christian Century in Japan, 64. Institutionalized Zen Buddhism had itself taken on immanentist functions too. 
the missionaries because they aligned with his determination to suppress the power of organized Buddhism seems justified. ${ }^{87}$

But the Jesuits undoubtedly exaggerated both Nobunaga's favor towards them and his detachment from the religious norms of his fellow warriors. As Kanda Chisato has shown, he continued to propitiate deities before battle. ${ }^{88}$ Any hopes that he would convert were deeply misplaced, and the conclusions that he drew from his actions were, of course, quite different to those of the missionaries. ${ }^{89}$ It is now time to explore the range of reasons why Christian iconoclasm was ultimately limited in the threat it posed to existing forms of Japanese religion. There were, to begin with, certain kinds of "conceptual control" available to supporters of the attacked institutions which may be found in almost any religious context. I have already referred to the inherent ambiguity of timing: misfortune at any point afterwards might be attributed to divine pique..$^{90}$ This fueled endless arguments between Christians and their critics over when and where the punishments of the gods might be manifest. ${ }^{91}$ The distinction between the local manifestations of gods in particular shrines and their more abstract overarching identities might allow the former to be confronted without implication for the latter. ${ }^{92}$ Otomo aggression towards the Usa Hachiman shrine may have been assisted by their long-standing connections to the Yusuhara Hachiman shrine.

More importantly, however, even those local manifestations were unlikely to be affected in the eyes of temple destroyers, given that one could draw a strong distinction between the gods per se and the people who purported

87 Elison, Deus Destroyed, 27; Ross, A Vision Betrayed, 52; McMullin, Buddhism and the State, 226-230 offers some qualifications.

88 Kanda Chisato 神田千里, "Ruisu Furoisu no egaku Oda Nobunaga-zō ni tsuite ルイス・ フロイスのえがく織田信長像について [On Oda Nobunaga from the Writings of Luis Frois]," Tōyō daigajku bungakubu kiyō 69 (2016): 49-76.

89 Luís Fróis, 1 June 1569, Cartas, ff. 256-268; Boxer, The Christian Century in Japan, 57, 64; Peter Nosco, "Early Modernity and the State's policies towards Christianity in 16th and 17thC Japan," Bulletin of Portuguese Japanese Studies 7 (2003): 7-21, 9.

90 For example, as early as the $155 \mathrm{os}$, some Japanese were already blaming continuing wars on the missionaries who had claimed that the hotoke "could not save themselves nor others," thereby causing the hotoke to take offence. (Fróis, Historia de Japam, I, 52).

91 For example, see the argument playing out in the wake of the defeat of Ōtomo Sōrin and Yoshimune's forces at the Battle of Mimigawa in 1578, in Fróis, Histotria de Japam, III, 118-119. After a temple and its scriptures were attacked by a zealous neophyte, a monk argued that the hotoke would exact a grave punishment in reply. Fróis delights in noting that, in fact, it was his fortune that took a turn for the worse and the temple was burned to the ground.

I'm grateful to a discussion with Christopher Mayo for this point. 
to venerate them in control of particular shrines and temples. ${ }^{93}$ As Thomas Conlan argues - in an analysis of how temple destruction worked in fourteenth century warfare - the sacred institutions of the enemy "were brutalized precisely because their destruction 'proved' that the gods supported one's own cause." 94

However, such arguments were surely given greater force by the way they could be expressed in a transcendentalist idiom arising from Buddhism and from Way of Heaven (Tentō) thought. The latter, derived from Confucianism, became particularly influential as an ethical understanding of fortune and misfortune among warrior elites in the sixteenth century. ${ }^{95}$ It was, to be sure, a concept in flux, being variously and flexibly understood and debated. ${ }^{96}$ There was certainly shared terrain with Christian notions of God or Providence as a judgmental supernatural agentive force, and this may have provided a kind of cognitive bridge for converting daimyo - although there were also points of difference and tension. ${ }^{97}$ As for the influence of Buddhism, the distinction between a local deity and its more encompassing form was surely enhanced by the process of honji suijaku, by which deities were conceived as trace manifestations of bodhisattvas with a far more universal reach and soteriological capacities. And the capacity to destroy a temple signified not just that one was divinely-blessed because one was powerful - but because one was just or righteous. In other words, the whole discourse of metapersonal agency was profoundly ethicized. In practice, this could still amount to a simple logic of might equals right. ${ }^{98}$ But cognitively, it meant that temple and shrine destroyers

93 Thanks to correspondence with Thomas Conlan here.

94 Thomas Conlan, State of War: The Violent Order of Fourteenth-Century Japan (Ann Arbor, 2003), 166, 174 .

95 Paramore, Japanese Confucianism, 42-45; Ooms, Tokugawa Ideology, 36, 45; zтноs, vol. 21, doc. 223, pp. 114-115, for a 1562 shrine supplication.

96 See the discussion in the editors' introduction to Ōta, The Chronicle of Lord Nobunaga, 43-44.

97 João Rodrigues, Vocabvlario da lingoa de Iapam (Nagasaki, 16o3), f. 255; Kanda, "Ōtomo Sōrin no kaishū,” 75-77; Kanda Chisato, Shūkyō de yomu sengoku jidai 宗教で読む戦 国時代 [Examining the age of the warring states through religion] (Tokyo, 2010), 53-54; Richard Bowring, "Searching for God in Neo-Confucianism," in Baskind and Bowring, The Myotei Dialogue, 32. Note Fabian Fucan, post-apostasy, on the difference with the Christian god 1620: "Dislikes, likes and personal preferences are personal feelings. Deus, who has love and hate is unworthy of consideration." (Refutation of Deus by Fabian, trans. E. Hibbard and Hiraishi Y. (Tokyo, 1963), 11).

98 Hence Emperor Ōgimachi congratulates Nobunaga for taking control of Mino province, saying that he was assisted by the "inspiration [or influence] of heaven": Lee Butler, Emperor and Aristocracy in Japan, 1467-1680 (Cambridge, MA, 2002), 290. 
could be represented not as opponents of the deities in question but as their true guardians - insofar as they incarnated the ethical-soteriological schema the deity was associated with and the piety with which they deserved to be venerated. Psychologically it cannot have always been straightforward to reassure oneself of this. ${ }^{99}$ But there were certainly means by which the argument could be advanced. ${ }^{100}$

Similar arguments could be advanced by supporters of Nobunaga. The chronicle of Nobunaga written by a former retainer in circa 1610 employed a righteous register in order to present the monks of Enryakuji as mired in spiritual corruption. ${ }^{101}$ Mount Hiei may be the guardian of the imperial capital, but the monks who resided on it "cared nothing for penances, ascetic exercises and monastic practices, and felt no shame at the derision of the realm. Heedless of the Way of Heaven and its terrors, they gave themselves over to lewdness, ate fish and fowl, indulged in bribery, and wallowed in gold or silver."102 (The terms used here indicate that the Jesuits' accusations of hypocrisy directed at Buddhist monks may have echoed local as well as European forms of anticlericalism). Similarly, for the year 1574, the chronicle asserts that the Ikkō-ikki were ignoring their own religious principles, no longer invoking Amida, and becoming "engrossed in worldly affairs." ${ }^{103}$ It is underlined that Nobunaga was therefore an agent of Tentō.

Indeed, such claims could be strengthened by the fact that, at the level of higher teaching at least, Buddhism contains its own transcendentalist disparagement of image worship and its own explanations for the misfortunes of the devout. In this respect it was thus comparable with Christianity. ${ }^{104}$ One dimension of this related to the idea that the world had entered the final age of the Dharma (mappō) in which Buddhism itself had degenerated. ${ }^{105}$ According

99 On signs that generals might regret their behavior of temple destruction and worry about the divine response to temple destruction, see Conlan, State of War, 192; Stephen Turnbull, The Samurai and the Sacred (Oxford, 2006), 96.

100 One course of action that presumably helped was rebuilding the shrine afterwards.

101 He was an eyewitness to some of the events he described, Öta, The Chronicle of Lord Nobunaga, $18-19$.

102 Ōta, The Chronicle of Lord Nobunaga, 165. Thanks to Kanda Chisato for discussion.

103 Ōta, The Chronicle of Lord Nobunaga, 210.

104 In Christianity, this potential bore fruit, of course, in Protestant iconoclasm towards Catholic "idol worship."

105 Note the reference in a 1562 shrine vow by Otomo vassals, ZTHOS, vol. 21, doc. 223, pp. 114115. Also see Francisco Cabral's intriguing report of a conversation with a Japanese nobleman on the decline of Buddhist law, in Linda Zampol D'Ortia, "The cape of the devil: Salvation in the Japanese Jesuit mission under Francisco Cabral (1570-1579)," (PhD Thesis, University of Otago, 2017), 198. 
to one Mahayana sutra, in this age the bodhisttavas would no longer use sacred images simply as a way of guiding lay people to the dharma but would use objects such as sutras and relics as an end in themselves, detached from the real objectives of learning, meditation, and compassion. ${ }^{106}$ In other words, the text betrays an anxiety about the immanentist misunderstanding of transcendentalist purposes. Rambelli and Reinders suggests that this form of ritual materiality was therefore seen as at once deformed and unavoidable, and that this might explain both the importance that the Japanese attached to ritual objects and the destructive violence wielded against them. ${ }^{107}$ Indeed, Rambelli argues that temple destructions were often justified as a means of defending true Buddhism against heretics and imposters who would speed up the End of Dharma - indicating a classic transcendentalist concern with truth, ethics, and salvation. ${ }^{108}$ The notion embedded deep in the societal logic of Buddhism that even secular forces could have an obligation to purify Buddhist establishments (which were no more immune from the degenerative forces of samsara than anything else) meant that iconoclasts had a moral high ground they could seek to occupy. ${ }^{109}$ The Mongol attacks of the late thirteenth century had been interpreted in some texts as "skillful means" deployed by the gods to revive the power of Buddhism. In this logic, "iconoclastic attacks against Buddhism were in fact the compassionate deeds of Buddha and kami."110 According to one medieval esoteric doctrine, Buddha's counterpart Māra, the symbol of chaos and destruction, also had a part to play in stimulating men towards higher things and signaling the inevitable degeneration of all that is earthly.111 This is an excellent example of the capacity of transcendentalism to subvert the normal significance of mundane misfortune by setting it within a higher frame of meaning. Temple destructions, and other forms of calamity might confirm rather than undermine Buddhist narratives.

106 The sutra of Great Treasures, Da baoji jing, by an Indian monk, Bodhiruci who journeyed to China, dated variously from the sixth to early eighth centuries CE.

107 Rambelli and Reinders, Buddhism and Iconoclasm, 28.

108 Rambelli and Reinders, Buddhism and Iconoclasm, 54, puts it slightly differently: “... in the name of alternative visions of sacredness, in turn based on ideas of orthodoxy, legitimacy and authority." They explicitly compare with European Christendom here.

109 Rambelli and Reinders, Buddhism and Iconoclasm, 61.

110 Rambelli and Reinders, Buddhism and Iconoclasm, 84.

111 Rambelli and Reinders, Buddhism and Iconoclasm, 81. 


\section{The Usa Hachiman Shrine Revisited}

A number of detailed documents relating to the shrine of Usa Hachiman give a concrete sense of how such issues of divine power and ethics were conceived over the sixteenth century. Moreover, Hachiman was presumably a major rival to the Christian deity in moments when missionaries and their opponents were locked into empirical arguments about success and failure. At the same time, he was also profoundly connected to Buddhism as a Great Bodhisattva (Daibosatsu). In other words, Hachiman's functions must be understood in both immanentist and transcendentalist terms.

There were many gods of war, to be sure, but Hachiman was easily the most significant, indeed he was associated particularly strongly with Japan itself and its imperial line. ${ }^{112}$ Nobunaga ordered a major restoration of Iwashimizu Hachimangū in the Kyoto region in $1579 .{ }^{113}$ Hachiman cultic sites had claimed responsibility for the kamikaze that had saved Japan from the Mongol invasion of 1274, and the deity would be invoked again by Hideyoshi in his 1592 invasion of Korea. ${ }^{114}$ One history of the Usa Hachuman shrine (Hachiman Usagū hōjō-e engi) tells us that in 721 the imperial court had sent it a petition for assistance with an uprising by the Hayato people. The oracle declared that the provinces of Ōsumi and Hyūga should be pacified and the deity would carry this out. ${ }^{115}$ And so, he did, in over three years of campaigning that brought about the imperial subjugation of Southern Kyushu. If it is striking how concrete the god's military services were imagined to be, we must also note that on his return the deity established the Rite for the Release of Living Beings (hōjo-e) as retribution for the slaughter involved. Therefore "even though he kills, because he has an enlightened status and does good, there is a lot of merit in his killing."116 As Christopher M. Mayo puts it, the shrine "reconciled the desire to wage war

112 Conlan, State of War, 173-174; Turnbull, The Samurai and the Sacred, 52, 57; Jien, The Future and the Past: A Translation and Study of the Gukanshō, an interpretative history of Japan, trans. Delmer Myers Brown and Ichirō Ishida (Berkeley, 1979).

113 Ōta, The Chronicle of Lord Nobunaga, 339.

114 Allan Grapard, "The Source of Oracular Speech: Absence? Presence? Or Plain Treachery? The Case of Hachiman Usa-Gū Gotakusenshū," in Buddhas and kami in Japan: Honji suijaku as a combinatory paradigm, ed. Mark Teeuwen and Fabio Rambelli (London, 2003), $77-94,78$, notes that it is "in the documents of this cult that one encounters the strongest xenophobic statements of the medieval period."

115 Jane Marie Law, "Violence, Ritual Reenactment, and Ideology: The "Hōjō-e" (Rite for Release of Sentient Beings) of the USA Hachiman Shrine in Japan," History of Religions 33 (1994): 325-357, 344. See also Grapard, Mountain Mandalas, 18-21, 208-212, for a sense of the complex development of narrative and Buddhicization in various textual traditions.

116 Law, "Violence, Ritual Reenactment, and Ideology," 345. 
with the task of bringing peace to the souls of the vanquished."117 Hachiman was thus not simply a "god of war" as the Jesuits described him, but was also a means of dealing with the moral quandary of violence. ${ }^{118}$

By 1533, Ouchi Yoshitaka (1507-1551), had pushed into Buzen and taken control of the area housing the Usa Hachiman shrine. In the following extract from Mayo's translation of the vow made by Yoshitaka, we see how directly the warlord attributed a range of outcomes to the favor of Hachiman, chief among them being victory in battle and the political consequences that follow: ${ }^{119}$

Observing the heavens we see the correct change of the seasons; the Earth opens and we obtain benefits that nurture us. The sun and moon shine without fail, the winds and clouds move as they should, and this is all the result of the outstanding virtue of the great deity, which shines forth without fail. Everyone is protected by the great power of the deity. Clearly, there is no power greater. It is to this awesome spirit that I make this sincere prayer.

Since the Autumn of last year in 1532, enemy forces have been attacking the borders of Buzen and Chikuzen. Yoshitaka gathered righteous armies (gihei) and fought them. Receiving the decision immediately, it was certainly heavenly fortune, and the aid of the gods (shinmyo eijo nari). The country [Chikuzen] was returned to peace, the harvests of the people were good, and beginning with my ancestor, Rinshō Taishi [A Korean king of antiquity], down through the generations we have been blessed with bravery, I have risen to high rank, I am the military governor

117 Christopher M. Mayo, "The Ōtomo and Competition in the Ritual Marketplace," in Ōuchi to Ōtomo: Chüsei Nishi Nihon no nidai daimyō 大内と大友 中世西日本の二大大名 [The Ōuchi and Ōtomo: Two major lords of western Japan during the Medieval Period], ed. Kage Toshio (Tokyo, 2013), 1-30, 6-7, drawing on Law, "Violence, Ritual Reenactment, and Ideology," who notes that the rite actually seems to combine the (immanentist) logic of the "appeasement ceremony" (chinkonsai), with a (transcendentalist) imperative of showing compassion for sentient beings.

118 Luís Fróis, 27 Aug 1585, Cartas, II, f. 155; Fróis, Historia de Japam, II, 51; João Rodrigues's Account of Sixteenth-Century Japan, ed. Michael Cooper (London, 2001), 97.

119 I am grateful to Christopher M. Mayo for discussions about Hachiman and other matters, and the following quotations come from Mayo 2013 using Ōuchi Yoshitaka Usagū zōryū no kōmon an 大内義隆宇佐宮造立之告文案 (Draft of vow to construct of Usa shrine by Ōuchi Yoshitaka), in "Masunaga monjo 益永文書 (Documents of the Masunaga)," 1533/7/23, Usa Jingū shi 宇佐神宮史 (A history of Usa shrine), ed. Takeuchi Rizō 竹内 理三 and Nakano Hatayoshi 中野幡能 (Usa, 1984-2012), Vol. 12, 92-93. Mayo points out that we cannot know how much input the shrine priests and his secretary had in phrasing the petition. Compare also with a vow at the shrine by one of Ōtomo Sōrin's vassals: Mayo, “Tachibana Dōsetsu's Thoughts on Warrior society," $57-58$. 
of the seven provinces, and I know the importance of heaven's mandate. I have received wealth and fortune, and like a cloud wandering the sky, I recognize that I ought to be in awe of heaven. There is no one who can challenge me as an enemy and I could not gain victory in battle without the protection of the deity. Mobilizing forces is not for the protection of my office, but to save the people from fire and ash. I implore you to use your supernatural powers on my behalf. If you do that, then I can bring peace to Kyushu. I can govern the three territories and I can put away the spear and shield. May the imperial office survive a long time, the gods of the earth and the five grains will have blessings bestowed upon them and may the emperor live long. I humbly offer up this prayer.

Hachiman seems here to be credited with grand cosmological responsibilities, with the movement of the heavens and the turning of the seasons. Indeed, the actual heavens, the functioning of the Way of Heaven, and the power of the deity all run together. Note in particular that the deity's powers are dependent on his virtue, and that for Yoshitaka to receive support, his armies must in turn be righteous. His victories must not be conceived as mere personal glory but as an instrument for the higher aim of peace. This presumably reflects the way that Hachiman had been enmeshed within a Buddhist sensibility, just as Buddhism itself had been surrounded with the immanentist pugnacity of a war god (literally, for Hachiman was a protector deity of Buddha). ${ }^{120}$ As a bodhisattva since $781 \mathrm{CE}$, Hachiman was not a being in need of salvation himself but rather an agent of salvation such that he could be represented in the guise of a Buddhist monk. ${ }^{121}$ The principle of honji suijaku had worked - not just in the theorizations of literati, but in the practice of a warrior's petition - to transcendentalize understandings of the god.

By 1561, it was observed above, the Usa Hachiman shrine was under the control of the Otomo, who had burned it to the ground in that year. ${ }^{122}$ A letter from an Ötomo retainer, Yoshioka Nagamasu, to one of the managers of

120 Bowring, The Religious Traditions of Japan, 92-93.

121 Mark Teeuwen and Fabio Rambelli, "Introduction: Combinatory Religion and the honji sujaku Paradigm in Pre-modern Japan," in Buddhas and Kami in Japan, eds. Teeuwen and Rambelli, 1-53, 13-14, 25; Mark Teeuwen, (2000) "The Kami in Esoteric Buddhist Thought and Practice," in Shinto in History: Ways of the Kami, ed. Mark Teeuwen and John Breen (Honolulu, 2000), 95-116, 95.

122 A letter from a group of Ōtomo vassals in 1561 to Nata Akimoto, the father of Ōtomo Yoshishige's wife, advises him how to deal with the head priest and warns him not to allow any unrest: Ōtomo-shi toshiyori rensho shojō an, document 418, in Ōita-ken shiryō, vol. 24 . 
the shrine, seeks to justify their actions, explaining that they did not foresee that the head priest would turn against them. ${ }^{123}$ But it then insists that Ōtomo Yoshishige will protect the shrine because "the blessing of the god is the most important thing for a winning campaign" and enjoins the shrine priests to confine themselves to praying for his military success. Indeed, the fact that both this retainer and Yoshishige himself became Buddhist lay priests the following year (Yoshishige thus became Sōrin) might suggest that they attributed their military success to the bodhisattva.

This was the period in which Sōrin was engaged with war with the Mōri, and the following year a group of his vassals donated a suit of armor to the shrine and made an appeal to the three Hachiman Bodhistattvas to give his support to their cause. ${ }^{124}$ Again, what is worth underlining here is the way in which the enemies of Hachiman and the enemies of Bungo are conflated through their impiety and immorality: they are described as chaos-creating bandits who "despised the Three Jewels (Buddha, the Dhamma, Sangha]," "distorted right and wrong" in the country, and wished to violate the Way of Heaven (Tentō). The Ōtomo, on the other hand, observed the Five Precepts [of Buddhism] and wielded authority through their commitment to protecting the Buddhist law and the imperial law [ buppō-ōbo $]$. Hachiman is supplicated to give victory - in the name of peace. ${ }^{125}$ In brief, shortly after burning down Hachiman's principal abode, the Ōtomo are presenting themselves as his very agents on earth.

\section{Christian Iconoclasm as a New Phenomenon}

Central features of Buddhism and Tentō thought therefore militated against the possibility that warrior shrine and temple destruction could be used to call into question their fundamental principles. How did Christian iconoclasm fit into - or alter - such schemas of perception? Indeed, how novel was it, in truth? In an important sense, it had been prefigured by the behavior of the

123 Letter of Yoshioka Nagamasu, 1561, in in Ōita-ken shiryō , vol. 2, document 17.

124 Bekki Akitsura and others, the 13th day of the 9th month, 1562, zTHOS, vol. 21, document 223. The three emperors, Chūai, Jingū, and Ōjin, are identified with Hachiman who is in turn equated with the Pure Land trinity of Amitābha, Avalokiteśvara, and Mahāsthāmaprāpta through the honji suijaku paradigm. See also the discussion in Kanda, "Ōtomo Sōrin no kaishū," 75-77.

125 See also the petition made by Sōrin's minister and brother-in-law (and the son of Nata Akimoto), Tawara Chikakata in 1568, donating armor and requesting the support of Hachiman against the Mōri: 8th day of the 9th month: Ōita-ken shiryō, vol. 24, document 430). 
exclusivist, militant sects of the Jōdo Shinshū Ikkō-ikki, and the Hokke followers of Nichiren, who were not above acts of desecration, as Kyoto saw to its cost in $153^{2-1534}$ when the two clashed in the streets. ${ }^{126}$ One Enryakuji monk wrote in 1482 that "Looking carefully at the actions of the followers of Honganji, we see that they slander the true doctrines of Buddhism, destroy the images of Buddha and the holy scriptures, and overturn shrines and temples."127 This could amount to a form of "righteous iconoclasm" insofar as it was propelled by arguments to do with truth, ethics, and salvation, and even at times approximate the Christian disregard for the power of the kami. ${ }^{128}$ It is not surprising then that of all the indigenous sects, the Christians were increasingly identified with these latter montō (leagues), as Sōrin's wife seems to have done quite explicitly in $1577 .^{129}$ For her, as for many Japanese elites, this was not a commendable analogy. Thus, two varieties of transcendentalism emanating from different ends of Eurasia came to resemble each other to the extent that they produced broadly comparable forms of iconoclasm. ${ }^{130}$

If the iconoclasms of followers of the radical forms of Kamakura Buddhism and Christianity were distinguished from more typical forms of daimyo temple destruction by the way they represented a more specifically religious conflict, Christian iconoclasm was, however, set apart in a more complete way. Converts were emboldened by discourses that not only legitimized actions with specific political purposes or retaliations in mind but were the basis for general policies instituted in peace time as well as war. Never before had there been attempts to wipe out Buddhism and kami worship tout court in the name of an entirely different system. ${ }^{131}$ The ruthlessness with which Christianity swept aside the most elemental features of Japanese religious pluralism was without real

126 Rambelli and Reinders, Buddhism and Iconoclasm, 57; Turnbull, The Samurai and the Sacred, 93-94.

127 Quoted in Bowring, The Religious Traditions of Japan, 424.

128 "As nearly as we can tell, most members of the Honganji sect understood the theology to mean that no gods (kami) or buddhas other than Amida had any real power over them." Carol Richmond Tsang, "Advance and Be Reborn in Paradise ...' Religious Opposition to Political Consolidation in Sixteenth-Century Japan," in War and State Building in Medieval Japan, eds. John A. Ferejohn and Frances McCall Rosenbluth (Stanford 2010) 91-109, 93.

129 Luís Fróis, 5 June 1577, Usuki, Cartas, f. 384.

130 See Philippe Buc, "Sectarian Violence in Premodern Japan and Europe: Jōdo Shinshū and the Anabaptists" Viator, forthcoming, for a comparison of Ikkōshū and Anabaptist violence, including iconoclasm.

131 Rambelli and Reinders, Buddhism and Iconoclasm, contrast the "medieval" mode of iconoclasm (53) with both the aggression of the unifiers and the "unprecedented" iconoclasms of Christian daimyo (63). 
parallel. ${ }^{132}$ In 1580, one of the Ōtomo's most senior retainers, Tachibana Dōsetsu, wrote a letter to thirteen senior retainers of Yoshimune, which includes a section reproving past bouts of Christian destruction and explicitly contrasting it with other forms of temple destruction:

These claims are written at the beginning of the [Akizuki's] letter, and if there is even a little truth to them, this would have been ill-advised. In your domain, from ancient times to the present, the temple and shrine lands have not been disturbed and we hear that historically people have been assigned to maintain them. This is very wise. Since the time of the Genpei [War 1180-1185], we have been told to pray for the protection of buddhas and kami, fulfil our obligations based on what is proper, and then take up the bow and arrow to fight. In Japan, it is already written how to deal with the temples and shrines. As a result, it does not even rise to the level of asking whether using images of buddhas and kami as firewood was good or bad, but one ought to naturally know it is senseless and beyond such distinctions. Japan is the land of the kami; in private and public matters, and in religious belief, we must act without going against the proper principles and Way of Heaven. ${ }^{133}$

After receiving this letter, these southern retainers of the Ōtomo acted upon it by writing in turn to Yoshimune's advisors to urge the point. ${ }^{134}$ It seems that Yoshimune had defended his actions by comparing himself with Nobunaga (thus confirming the report of Fróis). ${ }^{135}$ Their rejoinder is wonderfully apposite: Nobunaga's violence had not been directed against the gods and buddhas per se, but was determined by whether the temple was a military enemy or not. ${ }^{136}$ (This, of course, was quite true: Nobunaga punished certain recalcitrant institutions while supporting others.) ${ }^{137}$ Claims of imitating Nobunaga

132 Paramore, "Christianity as Feudal Virtue or as Civilization Mission?" 408, notes that antiChristian propaganda and official anti-Christian edicts after 1612 often refer to the use of force by Christians to convert others, as well as Christian non-acceptance of religious pluralism, as justifications for the state ban on the religion.

133 Tachibana-ke bunsho 立花家文書 16 Feb 1580. ZTHOS, vol. 24, doc. 406, pp. 214-215. This translation is by Xia-Kang Ziyi, drawing on the helpful translation and commentary in Mayo 2015 .

134 ZTHOS, vol. 24, doc 408, See also the discussion by Kanda "Ōtomo Sōrin no kaishū," 102, and also Kanda, Shūkyō de yomu sengoku jidai, ${ }^{8}{ }^{-59}$.

135 Note the claims by Luís Fróis noted above (16 Oct 1578, Usuki, f. 424; 5 June 1577, Cartas f. 377v), that Yoshimune explicitly compared himself with the great man.

136 Zтноs, vol. 24, doc 408, 230-231.

137 McMullin, Buddhism and the State, 56-57, 163, 167, 217-220. 
were either disingenuous or blind: there was no precedent for destroying temples and shrines which were entirely blameless. Yoshimune had valued "greed" (yoku) over righteousness ( gi), had forsaken Buddhist and Confucian virtues appropriate to his role as a ruler, and been dragged into the mire with his father who had "destroyed the buddhas and kami" by attacking the temple and shrines of his own sect. ${ }^{138}$

In 1587 , Hideyoshi's expulsion edict made the point very explicitly:

Japan is the land of the Gods and so it is undesirable that evil doctrines from Christian lands be propagated. To approach the inhabitants of our lands, make them into followers and destroy shrines and temples is unprecedented behaviour. ${ }^{139}$

All these statements insist upon the distressing novelty of Christian iconoclasm. This is not surprising given that it set out to pose a direct challenge to the kami and the entire combinatory belief system that sustained them. ${ }^{140}$

\section{Conclusion}

The immanentist intuition that temple destruction might incur the wrath of the gods had long found expression in Japan. This opened up the possibility of claims of disconfirmation should vengeance not be forthcoming, particularly where the target was the local manifestation of a god, or a particular shrine, or belonged to an opposing sect. Furthermore, under the conditions of the Sengoku period, daimyo inevitably clashed with various Buddhist institutions including shrines, temples, monasteries and lay leagues. As the career of Nobunaga reached its height there had been some quite stunning demonstrations that - for whatever reason - the gods would not necessarily punish those who destroyed their abodes. Clearly, the likes of Sorin and Yoshimune took note. This provided some cover for daimyo wishing to release the resources locked up in such institutions for their own ends, or drawn to experimentation with the new faith - or some such vaguely unconscious and blurred combination of the two.

138 ZTHOS, Vol. 24, doc 408, 238.

139 Richard Bowring, In Search of the Way: Thought and Religion in Early-modern Japan, 15821860 (Oxford, 2017), 15.

140 In other words what Rambelli and Reinders, Buddhism and Iconoclasm, 176, refer to as "the semiotic labour and effects involved in iconoclastic acts" were profoundly different in the case of Christian activity. 
But there were transcendentalist discourses which strengthened the "conceptual control" of supporters of Buddhism and kami shrines in cognitively coming to terms with these desecrations - weakening, in other words, any "disconfirmation" effect. Local deities were identified with more universal and Buddhicized metapersons who were understood as behaving according to ethical and soteriological principles. It could be argued that those who destroyed temples were the true guardians of the causes they represented. Nobunaga's feats may have been breath-taking in their audacity and their capacity to usher in a new dispensation of religio-political relations - but they were not designed to undermine either Buddhism or kami worship and nor was that their overall effect.

Christian iconoclasm was then quite different in intent - and, it would seem, in the interpretations and reactions it elicited. Christian daimyo did not seek to insert themselves into existing visions of eschatological time but asserted an entirely different understanding of what eschatology was; they did not claim that they truly upheld the kami and the hotoke but that these "gods" were mere demons. This helped drive the growing apprehension that Christianity represented a uniquely potent threat to social order and Japanese tradition - in some ways equivalent to that posed by radical movements issuing from the Kamakura schools, but in other ways more disturbing still. ${ }^{141}$

The work of iconoclasm was part of a wider field of "empirical religiosity" which shaped understandings of military action, political success, and bodily health above all. ${ }^{142}$ Over decades, arguments raged - between Christians on the one hand and Buddhist and kami temple/shrine supporters on the other - over which metapersons and rituals and objects were more efficacious at winning battles and healing the sick. In this context, as in many other cases of conversion to Christianity in global history, iconoclasm was employed as a dramatic means of proving the weakness of local metapersons. Again, as in other mission fields, this theatre of immanent power helps explain the element of popular participation, and indeed why such "forced" or top-down conversions in Kyushu domains could endure. But there were real limits as to the strength of such arguments in Japan. Missionaries were operating in a land where temples had long been attacked, and all manner of calamities might be

141 The points made by Tachibana Dōsetsu and Hideyoshi were reiterated by Ieyasu in 1605, who again pointed out the problem with iconoclasm given that "ultimately, our country is the Country of the Gods and what you call 'idols' have been respectfully venerated by our ancestors." Ooms, Tokugawa Ideology, 47.

See Strathern, "Immanent power and empirical religiosity." 
set within a transcendentalist frame that ultimately surpassed the reach of the merely empirical.

\section{Acknowledgements}

I would like to thank Xia-Kang Ziyi for translating all the primary sources in Japanese used here unless otherwise mentioned, as well as some secondary literature, and Ian Macdonald for other translation work. I'm grateful to Christopher M. Mayo for help with many matters in relation to Japan and the Ōtomo, and to Kanda Chisato for extreme generosity in assembling Japanese sources and discussing them. Professor Kanda also read an older, longer text from which this article has been extracted, as did Kiri Paramore, Richard Bowring, and James McMullen - I am grateful to all. Yuki Moriwaki helped me to access libraries and sources in Japan, and Thomas Conlan entered into discussion of some important points by email. Lastly, I am very grateful for the in-depth comments of the two anonymous readers for the journal, from which I learned a great deal. 